\title{
Estereótipos em sessões de mediação de aprendizagem em Teletandem
}

\author{
Ludmila Belotti Andreu Funo \\ Universidade Estadual Paulista "Júlio de Mesquita Filho" (UNESP), \\ Assis, São Paulo, Brasil \\ ludmilabafuno@gmail.com \\ https://orcid.org/0000-0001-9857-8297
}

\section{DOI: http://dx.doi.org/10.21165/el.v47i2.2020}

\section{Resumo}

Este artigo apresenta o estudo de dois casos vinculados ao contexto Teletandem de aprendizagem de línguas (um contexto virtual, multimodal, autônomo e telecolaborativo de aprendizagem de idiomas). Segundo uma perspectiva interpretativista, apresenta-se a análise de trechos de sessões de mediação da aprendizagem nos quais os participantes de pesquisa fizeram referências explícitas a estereótipos, relacionando-os à cultura e à identidade. $\mathrm{O}$ objetivo da análise aqui proposta é compreender e problematizar as práticas sociais performatizadas através da perpetuação de estereótipos culturais.

Palavras-chave: estereótipos; identidades culturais; Teletandem.

\section{Stereotypes in Teletandem learning mediation sessions}

\begin{abstract}
This article presents two case studies concerned to Teletandem language learning context (a virtual, multimodal, autonomous and telecollaborative language-learning context). According to an interpretative perspective, this article presents the analysis of excerpts from learning mediation sessions in which research participants made explicit references to stereotypes, relating them to culture and identity. The aim of the present analysis is to understand and to problematize social practices performatized through the perpetuation of cultural stereotypes.
\end{abstract}

Keywords: stereotypes; cultural identities; Teletandem.

\section{Introdução}

O presente estudo se baseia na análise interpretativista de seis excertos, extraídos de transcrições de gravações em áudio feitas durante encontros chamados "sessões de mediação", em que aprendizes de línguas estrangeiras e professores mediadores, vinculados ao projeto Teletandem, se reuniam para compartilhar reflexões sobre as experiências vividas nas sessões de Teletandem (ou seja, encontros virtuais, multimodais, nos quais falantes de diferentes idiomas interagem com o intuito de aprender um a língua do outro). A análise dos dados enfoca os excertos nos quais a expressão estereótipo é declarada e enfatiza as significações que são tecidas em torno desse vocábulo.

Estereótipo é um termo muito recorrente no universo das relações cotidianas. Fala-se, lê-se e escreve-se corriqueiramente sobre estereótipos. Nos discursos que permeiam as interações sociais, é possível identificar materializações (ou formulações) 
que se enquadram como estereotipização. Pereira, Modesto e Matos (2012) citam, como exemplo da popularidade do termo, que, ao se googlear ${ }^{1}$ a palavra "estereótipos" é possível deparar-se com mais de dois milhões de resultados.

No universo acadêmico, a utilização do termo também é vasta. Há uma enorme variedade de estudos científicos que se filiam a diferentes áreas do saber e que contam com a ajuda de diferentes abordagens e procedimentos dedicados a investigar os estereótipos. Também há uma enorme variedade de possibilidades de estereotipização, todas vinculadas aos eixos que projetam as identidades (gênero, orientação do desejo, religião, casta, nacionalidade, etnia, classe, filiação política, por exemplo), como demonstra este estudo. Desse modo, é possível afirmar que a variedade dos estudos e das disciplinas que se voltam para a investigação dos estereótipos (e de todas as realidades humanas histórico-sociais a eles relacionadas) é tanto indício da complexidade do fenômeno, quanto da importância da constante atualização de seu entendimento para a vida em sociedade.

A pluralidade de estudos sobre estereotipização, por sua vez, engendra maneiras diferentes de entender e definir estereótipos. Eventualmente, na literatura acadêmica, é possível deparar-se com definições de estereótipos que trazem em seu bojo a ênfase sobre o entendimento de que essas representações se materializam graças a um movimento de simplificação de um conjunto de características homogêneas ou repetitivas de algumas pessoas, ou de alguns grupos sociais. Em outras palavras, seriam padrões de conduta, traços étnicos comuns, por exemplo, cuja "rigidez" (stereo) permitiria o esboço de um "traço" (tupus) ou rótulo (PEREIRA, 2002). Tais estudos são como uma "apologia", em sentido positivo, aos estereótipos, pois os trazem entendidos como um fenômeno humano, inevitável, e como forma rudimentar de delinear algum tipo de saber ou conhecimento sobre aqueles que foram rotulados, naturalizando os traços entendidos como recorrentes.

Para Orlandi (2004, p. 39-45), por exemplo, a noção de estereótipo está ligada à possibilidade de cristalização de sentidos e, embora eles tragam em seu bojo uma perspectiva "simplificada", os estereótipos podem ser desencadeadores de reflexões capazes superar o "simplismo" de suas construções:

\begin{abstract}
Mesmo que esta noção seja marcada pela noção de preconceito, inexatidão, crença geral, ela traz consigo a ideia de estabilidade e esta, certamente, será a base de muitas reflexões que não se limitarão ao simplismo das oposições: individual/social; criativo/banal; crença/realidade etc. Assim, chegamos à ambivalência dessa noção que faz entrar para a reflexão a relação do indivíduo com o outro e consigo mesmo, dos grupos com seus membros etc. [...] podemos dizer que ultrapassamos com esta noção a questão da falta de originalidade para chegar a das mediações sociais e da "comunicação".
\end{abstract}

Outros estudos, por sua vez, enfatizam na estereotipização seu caráter opressivo e alienante, entendendo sua manifestação como força aniquiladora da heterogeneidade humana dentro das culturas, dos grupos sociais, das comunidades. Para as pesquisas que trazem em si essa perspectiva, a estereotipização assume o papel de uma mediação imposta, como um quadro regulador das vivências sociais. São estudos que enfatizam

\footnotetext{
1 “Googlear", ou "guglar", são neologismos usados nas literaturas (e em outros meios) para enfocar as práticas virtuais vinculadas às buscas pelo aplicativo de pesquisa chamado Google. Se "googlearmos" buscando pelo verbo "googlear", por exemplo, encontraremos aproximadamente 323.000 resultados, o que atesta sua crescente popularidade e recorrência. Para saber mais, ler Canclini (2008).
} 
nas formulações que materializam esses estereótipos seu caráter ideológico ${ }^{2}$, bem como as bolhas sociais que eles engendram.

Ambas as perspectivas contribuem para o enriquecimento da compreensão do que são estereótipos, como surgem, por quais razões persistem e quais consequências imprimem. E, entre essas perspectivas e suas ênfases, que foram apresentadas como um esboço de polos que se complementam, há a possibilidade de serem delineados interstícios. Uma dessas possibilidades será apresentada neste artigo, que, dentro de suas limitações, busca apresentar os estereótipos como parte de uma dinâmica interpelativa (ALTHUSSER, 1970).

Destarte, no presente estudo - que, de modo introdutório, traz reflexões embasadas na análise interpretativista de dados coletados através de gravação em áudio em dois contextos distintos (considerados dois casos) ligados às dinâmicas de ensino e aprendizagem de idiomas dentro do projeto Teletandem ${ }^{3}$ - estereótipos são definidos como representações sócio-históricas, vinculadas aos eixos que compõem caleidoscópicamente nossas identidades, mais especificamente, entende-se que o estereótipo é uma formulação simbólica (que pode se materializar linguisticamente, por imagens, melodicamente etc.) que interfere na realidade viva das pessoas, no agora, nos modos de significar, pois assume-se o estereótipo como interpelativo, assujeitador, generalizante, homogeneizante, rígido e ideológico.

\section{Fundamentação teórica}

Esta seção tem por finalidade apresentar o horizonte interpretativo com o qual a análise deste estudo dialoga, apresentando os conceitos-chave desta pesquisa, que são: estereótipos, interpelação e ideologia.

\section{Estereótipos}

Lippmann (1922), em obra intitulada Public Opinion, é considerado uma importante referência nos estudos sobre estereótipos, pois desenvolve uma discussão calcada em uma concepção platônica de uma cisão existente entre o mundo sensível (the world) e as imagens representativas que delineamos sobre esse universo factual (ou as figuras dentro de nossas cabeças, como tradução livre de: the pictures in our heads), argumentando que as representações coletivas (ou opiniões públicas) sobre os fatos funcionariam como versões simplificadas da realidade que conduziriam as ações das pessoas:

\footnotetext{
As imagens [ou representações] dentro das cabeças desses seres humanos, as figuras de si, dos outros, de suas necessidades, propósitos e relacionamentos são suas opiniões públicas [letras minúsculas]. Aquelas imagens [ou representações] que são postas em prática por grupos de pessoas, ou pelos indivíduos que agem em nome de um grupo, são suas Opiniões Públicas com letras maiúsculas. E assim, ao longo dos próximos capítulos, vamos procurar em primeiro lugar
}

\footnotetext{
${ }^{2}$ Entendendo ideologia conforme proposto por Chauí (1980).

${ }^{3}$ Para saber mais, acesse: $<$ http://www.teletandembrasil.org/ $>$.
} 
algumas das razões pelas quais essas imagens [ou representações] enganam o homem em sua relação com o mundo exterior. (LIPPMANN, 1922, p. 16, tradução nossa) ${ }^{4}$.

Para o autor, os estereótipos são decorrência dessas imagens equivocadas que as pessoas constroem em suas cabeças, sendo características dos estereótipos a obtenção através do relato alheio, a simplificação, a falsidade e a resistência a mudanças, por exemplo.

Já para Baccega $(1998$, p. 7), os estereótipos impõem às relações interpessoais uma "carga negativa de preconceitos e pré-juízos [...], condicionando comportamentos de repúdio ao outro", assim os estereótipos, definidos pela autora como representações marcadas pela presença de impressões superficiais, generalizantes, calcadas em "aspectos valorativos", que engendram "versões recorrentes" e "padronizadas" da realidade (BACCEGA, 1998, p. 7), ou que "refletem [a realidade] com desvios" e dissimulação (BACCEGA, 1998, p. 10) teriam, então, o poder de interferir no modo como as pessoas enxergam, entendem e lidam com a vida social (o que inclui a relação entre as culturas e as identidades culturais).

Contudo, conforme apontado por Baccega (1998) em sua reflexão sobre as diferenças entre conformidade e conformismo, existe a possibilidade de se desestabilizar visões estereotipadas da realidade pela vivência e, sobretudo, pela educação escolar, tendo essa última o importante papel de oferecer condições de inserção social e emancipação aos movimentos conformistas que anulam as subjetividades através das dinâmicas massificadoras da vida cotidiana:

Quando se fala em estereótipo, é preciso ter clara a distinção entre conformidade e conformismo, pois o estereótipo tem uma multiplicidade de faces. Na verdade, o indivíduo acaba por orientar-se através de estereótipos e de normas, conformando-se ao seu grupo, buscando garantir o êxito de suas ações e a aceitação social. [...] Há que se estar atento, porém, para o fato de que essa conformidade que, no limite, faz parte da natureza do viver em sociedade, pode converter-se em conformismo, quando não são oferecidas ao indivíduo/sujeito possibilidades reais de inserção na sua sociedade, numa interação em que ele seja efetivamente sujeito, em que ele tenha voz e sua voz seja respeitada. (E aqui a escola desempenha papel fundamental.) Nesse caso, os procedimentos e atitudes da vida cotidiana, que se regem pela conformidade com o estabelecido, acabam por penetrar em outras esferas da sociedade: o indivíduo/sujeito "vê" o que deixaram pronto para ele através da inculcação de estereótipos, passando a ser apenas a "voz do dono", deixando de lado sua condição de "dono da voz" (BACCEGA, 1998, p. 8-9).

Outro estudo que lança luz sobre a relação entre estereótipos e identidades é o da autora Biroli (2010) que, ao analisar as questões de gênero que cerceiam a presença das mulheres em noticiários políticos e em revistas semanais no Brasil, propõe uma discussão sobre os estereótipos que permeiam a compreensão social acerca do papel de homens e mulheres nesses espaços midiáticos. A partir de sua análise, a autora chega à conclusão de que existem marcas de gênero na maneira como as mulheres estão representadas nos espaços estudados e essas marcas dialogam com alguns estereótipos referentes ao espaço feminino na sociedade (privado) e o espaço masculino (público), pois para a autora:

\footnotetext{
4 The pictures inside the heads of these human beings, the pictures of themselves, of others, of their needs, purposes, and relationship, are their public opinions. Those pictures which are acted upon by groups of people, or by individuals acting in the name of groups, are Public Opinion with capital letters. And so in the chapters which follow we shall inquire first into some of the reasons why the picture inside so often misleads men in their dealings with the world outside. (LIPPMANN, 1965, p. 16).
} 
É possível perceber uma oscilação entre uma expectativa de que a mulher se apresente, na política, enquanto mulher, e um conjunto de julgamentos referenciados pela presença masculina na política e por representações da masculinidade, conectando a competência na esfera pública a atitudes entendidas como masculinas ou masculinizadas. (BIROLI, 2010, p. 296).

Assim, as formas segundo as quais a feminilidade é representada e compreendida (entre elas os estereótipos) interferem nos modos de inclusão e de exclusão sociais que regulam a presença das mulheres nos contextos estudados, visto que, para a autora, "identidades distintas são conectadas em discursos comuns sobre a feminilidade e sobre as relações entre mulheres e política" (BIROLI, 2010, p. 297). Cabe ressaltar que, segundo Biroli (2010), essa força constritiva não se manifesta de modo linear, pois, conforme a análise apresentada pela autora em face ao arcabouço teórico com o qual ela dialoga, essas representações sobre o espaço destinado socialmente à feminilidade, que normalmente restringem a atuação da mulher em contextos políticos, podem também servir de "estratégia de diferenciação e ação" a partir das quais haveria a possibilidade de engendrar mudanças às identidades de gênero (BIROLI, 2010, p. 297).

A presente pesquisa reconhece o valor social das contribuições de Lippmann (1922), contudo se aproxima de reflexões como as apontadas pelas autoras Biroli (2010) e Baccega (1998), pois estas já ultrapassaram a perspectiva fragmentária que concebe o mundo real e o conhecimento humano como fenômenos totalmente indiferentes e dissociados e, além disso, também consideram os estereótipos como representações passíveis de transformação, seja por experiências de vida pessoal, seja por experiências vividas em contexto formal de educação.

\section{a. Interpelação:}

Althusser (1970) se dedicou a refletir sobre a ideologia no Estado capitalista. Para esse autor, o Estado não deve ser definido apenas como um aparelho repressivo, cujas dinâmicas de funcionamento se dariam "massivamente" (ALTHUSSER, 1970, p. 46-47) pela violência, mas deve ser entendido também como um aparelho ideológico:

É que em si mesmo o Aparelho Repressivo do Estado funciona de uma maneira massivamente prevalente pela repressão (incluindo física), embora funcione secundariamente pela ideologia. Não há aparelho puramente repressivo. Exemplo: o Exército e a Polícia funcionam também pela ideologia, simultaneamente, para assegurar a sua própria coesão e reprodução e pelos valores que projetam no exterior. Da mesma maneira, mas inversamente, devemos dizer que, em si mesmos, os Aparelhos Ideológicos de Estado funcionam de modo massivamente prevalente pela ideologia, embora funcionando secundariamente pela repressão, mesmo que no limite, mas apenas no limite, esta seja bastante atenuada, dissimulada e simbólica (não há aparelho puramente ideológico).

Althusser (1970) dá o exemplo do policial que, ao chamar por um homem que anda pela rua, dizendo "ei, você aí!", representaria a ideologia interpelando esse indivíduo como um sujeito, assujeitando-o, sem que esse indivíduo tivesse a consciência de que estaria sendo interpelado ideologicamente. Assim, para Althusser (1970, p. 94) ideologia e sujeito são dois conceitos entrelaçados, segundo o próprio autor:

Segue-se que, tanto para vocês como para mim, a categoria de sujeito é uma "evidência" primeira (as evidências são sempre primeiras): está claro que vocês, como eu, somos sujeitos (livres, morais, etc.). Como todas as evidências, inclusive as que fazem com que uma palavra "designe uma coisa" ou "possua um significado" (portanto inclusive as evidências da 
"transparência" da linguagem), a evidência de que você e eu somos sujeitos - e até aí não há problema - é um efeito ideológico, o efeito ideológico elementar.

Outro aspecto que deve ser pontuado sobre ideologia na obra de Althusser (1970) é a concepção de uma dinâmica de subordinação ideológica, na qual cada aparelho ideológico do Estado (como as igrejas, o ministério da cultura etc.) tem sua existência assegurada por sua subordinação a uma ideologia dominante, sendo que essa ideologia dominante está imediatamente vinculada à manutenção dos processos de produção capitalistas e de divisão de classes sociais.

Essa reflexão tenta retraçar o caminho do poder e possibilita identificar naquilo que é formulado, ou seja, linguisticamente materializado, os rastros da ideologia, entendida como força que permeia e estrutura toda forma de significação inscrita na história de nossas sociedades. É sobre esses vestígios de poder que este trabalho se debruça, pois são esses vestígios que permitirão identificar os mecanismos de assujeitamento que delimitam e regulam as inscrições dos sujeitos na história e na sociedade, pois tais indícios ajudam a identificar as vibrações determinísticas da ideologia na linguagem.

\section{b. Ideologia e seu funcionamento}

Ainda sobre ideologia, é de suma importância para este estudo nos voltarmos às reflexões breves que Marilena Chaú teceu sobre o tema na década de 80, em um texto intitulado "Ideologia e Educação". Segundo a autora, a ideologia possuiria cinco características discriminatórias: caráter prescritivo/ normativo, caráter universal, invisibilidade, coerência e manipulação discursiva (CHAUÍ, 1980, s/p).

- Caráter prescritivo/normativo, para a autora, se relaciona ao fato de que "a ideologia predetermina e pré-forma os atos de pensar, agir, querer ou sentir, de sorte que os nega enquanto acontecimentos novos e temporais".

Ou seja, a ideologia antecederia o dizer, pré-determinando as formulações que seriam cabíveis nesse ou naquele contexto enunciativo e faria o mesmo com o vestir, por exemplo. Essa perspectiva assume um certo descentramento do sujeito, que deixa de ser entendido como fonte e origem de suas palavras e ações e passa a ser uma realidade que se materializa ao formular essas palavras e ações, ao performatizá-las, em uma dinâmica de assujeitamento e interpelação.

- Caráter universal/alienador, ocorre porque a ideologia produziria uma falsa impressão de universalidade, impondo para toda a sociedade (através de mecanismos de generalização) os interesses de um determinado grupo social.

- Invisibilidade, relaciona-se, para a autora, ao fato de a ideologia construir um sistema imaginário que ganha o status de natural ("como verdade igualmente aceita por todos") no qual os indivíduos conseguem identificar seus posicionamentos, fazendo com que as pessoas legitimem, involuntariamente, um sistema de relações sociais que favoreça os interesses do grupo social dominante;

- Coerência dupla, Chauí (1980) explica que a impressão de coerência de um sistema ideológico é imprescindível para sua manutenção, justamente, por ser conquistada por dois mecanismos, sendo eles (a) lacuna e (b) eternidade. 
O mecanismo de lacuna seria estruturado pelos apagamentos e silenciamentos, os quais funcionariam como andaimes para a sustentação da ideologia, sendo constitutivos de nossas formulações e performances. Assim, para ela, quando se consegue rastrear os vestígios desses apagamentos, se produz "um contra-discurso da ideologia", pois ao se explicitar o que foi silenciado agridem-se os discursos que antes silenciavam.

O mecanismo da eternidade retoma a ideia de invisibilidade, visto que "a lógica ideológica só pode manter-se pela ocultação de sua gênese" (CHAUÍ, 1980, s/p).

- Manipulação discursiva, segundo Marilena Chauí (1980), citando Claude Lefort (1979), transformar o discurso de em um discurso sobre é uma das operações fundamentais da ideologia, ou seja, "onde não pode haver um discurso $d a$ revolução surge outro, sobre revolução; onde não pode haver um discurso da mulher surge um discurso sobre a mulher" (CHAUÍ, 1980, s/p). Nesse sentido, o discurso sobre camuflaria seu caráter ideológico ao se autoproclamar teoria.

As considerações de Marilena Chauí (1980) sobre ideologia são trazidas porque dialogam com a análise dos dados do presente estudo, bem como com o arcabouço teórico explorado até então, sendo de suma importância para que se possa compreender a dinâmica discursiva dos sentidos sobre estereótipos tecidos nos excertos que serão analisados.

\section{Metodologia}

A presente pesquisa se configura como um estudo qualitativo interpretativista de dois casos, ou seja, de dois contextos especificos, formados por dois grupos distintos de pessoas que se reuniam em encontros chamados de "sessões de mediação de aprendizagem". Esses encontros eram vinculados ao projeto Teletandem de aprendizagem de línguas, que oferece oportunidade de aprendizagem de línguas estrangeiras de modo colaborativo, virtual e autônomo para alunos universitários brasileiros em parceria com universidades estrangeiras.

Um dos contextos, nomeado de Caso 1, se materializou em 2011, tendo envolvido em suas dinâmicas alunos de inglês como língua estrangeira, professores mediadores, pesquisadores em formação (todos participantes deste estudo, conforme Quadro 1, que será apresentado a seguir). O outro contexto, chamado de Caso 2, se materializou no ano de 2012 e envolveu aprendizes de espanhol como língua estrangeira, professores mediadores, pesquisadores em formação (todos participantes deste estudo, também conforme será apresentado no Quadro 1 a seguir): 
Quadro 1: Descrição dos casos estudados

\begin{tabular}{|c|c|}
\hline Grupo de Transcrições 2011: caso 1 & Grupo de Transcrições 2012: caso 2 \\
\hline Português/ Inglês (Caso 2; Código M2) & Português/ Espanhol (Caso 3; Código M3) \\
\hline $\begin{array}{l}\text { Perfil dos colaboradores do caso 2: } \\
\text { interagentes brasileiros (universitários que faziam } \\
\text { Teletandem institucional não integrado) os quais } \\
\text { tiveram parceiros majoritariamente estadunidenses } \\
\text { (universitários que faziam Teletandem institucional } \\
\text { integrado). }\end{array}$ & $\begin{array}{c}\text { Perfil dos colaboradores do Caso 3: } \\
\text { interagentes brasileiros (universitários que } \\
\text { faziam Teletandem institucional não integrado) } \\
\text { os quais tiveram parceiros mexicanos } \\
\text { (universitários que faziam Teletandem } \\
\text { institucional não integrado). }\end{array}$ \\
\hline Horas transcritas: $2 \mathrm{~h} 20 \mathrm{~m}$ aprox. & Horas transcritas: $2 \mathrm{~h} 40 \mathrm{~m}$ aprox. \\
\hline Meses de coleta: set./out./nov. de 2011 & Meses de coleta: set./out./nov. de 2012 \\
\hline $\begin{array}{l}\text { Total de Sessões: } 7 \\
\end{array}$ & \\
\hline $\begin{array}{c}\text { Nomes fictícios dos participantes envolvidos } \\
\text { Mediador: Francisco } \\
\text { Professora convidada } 1 \\
\text { Professora convidada } 2\left(\text { Kristin }^{5}\right) \\
\text { Interagentes: Akemi }{ }^{6} \text {, Alberto, Carla, Flávia, Jorge }{ }^{7} \text {, } \\
\text { Laura, Luísa, Mariana, Ricardo, Rosely, Alice, Ana e } \\
\text { Samira. }\end{array}$ & $\begin{array}{c}\text { Nomes fictícios dos participantes envolvidos } \\
\text { Mediadoras: Janaina, Kristin*e Lucrécia } \\
\text { Interagentes: Jorge*, Gesebel, Isaias, Leandro, } \\
\text { Alice, Brenda, Larissa, Laila, Carla, Tatiane, } \\
\text { Lucas, Roseli, Amarílis, Gisele, Deise, Elisabete } \\
\text { e Alaíde. }\end{array}$ \\
\hline
\end{tabular}

Fonte: Adaptado de Funo (2015), contendo informações sobre material documentário e colaboradores do estudo (nomes fictícios) em panorama geral e sintético

Assim, os dados deste estudo compreendem transcrições de áudios que foram coletados ao longo dos anos de 2011 e 2012, por meio do uso de gravadores de voz digitais nos formatos WMA/MP3. Tais excertos também fazem parte dos encaminhamentos de uma pesquisa de doutorado já concluída (FUNO, 2015). Cabe ressaltar que, aos participantes deste estudo, foram atribuídos nomes fictícios, bem como foram ocultadas quaisquer informações que pudessem identificá-los.

O enfoque da análise recai sobre os excertos nos quais o tema dos estereótipos foi abordado explicitamente, ou seja, esse foi o recorte utilizado para a seleção dos dados do material documentário coletado. $O$ interesse da análise foi o de interpretar as ocorrências destacadas da coleta, deflagrando as relações que são tecidas entre aquilo que foi dito sobre os estereótipos e os discursos que sustentam esses dizeres.

A hipótese é a de que existe algo de especial em se considerar formulações nas quais estereótipos são tratados de modo explícito, pois nelas deverá haver a materialização das tentativas de significação que envolvem o termo em suas riquezas polissêmica e contraditória. Ou seja, existiria nessas formulações uma certa pretensão de autoria, uma vez que os sentidos estão conectados às experiências vividas, singulares, mas essa pretensão de autoria esbarraria em outra provável característica dessas formulações: elas também se refeririam às representações socialmente compartilhadas sobre nacionalidades, por exemplo. Assim, será na tensão entre a singularidade e o socialmente compartilhado que a análise deste estudo será tecida.

\footnotetext{
${ }^{5}$ Kristin (nome fictício), era professora pesquisadora e estava presente nos dois contextos de coleta.

${ }^{6}$ Akemi (nome fictício) cursava Psicologia, e não licenciatura em Letras, como os demais colaboradores deste estudo.

${ }^{7}$ Jorge (nome fictício) está presente em dois casos (caso 2 e caso 3). Essa informação é relevante para a análise dos excertos apresentados neste estudo.
} 
Tendo em mente os construtos teóricos elencados na fundamentação teórica desta pesquisa, bem como as informações contextuais e a abordagem metodológica que a constituem, será apresentada na seção a seguir a análise dos dados, ou seja, a interpretação dos seis excertos nos quais estereótipos foram explicitamente citados.

\section{Análise dos dados}

Conforme foi citado na metodologia deste artigo, o corpus deste estudo está relacionado a uma coleta pensada para uma tese de doutorado (FUNO, 2015), que, embora tivesse interesse em interpretar as tramas que sustentam as identidades culturais em encontros virtuais entre interagentes que se identificam como pertencentes a nacionalidades e culturas distantes, por sua vez, não contemplava nenhum questionamento acerca de estereótipos especificamente. Mas quiseram as brechas e os inacabamentos da tese em questão duas coisas:

(a) que referências explícitas a estereótipos fossem feitas; e

(b) essas citações trouxessem considerável riqueza para o debate sobre as relações sócio-históricas entre pessoas que se identificam como pertencentes a culturas e nacionalidades distintas.

Essa é a trama que envolve o enxuto corpus que apresento neste estudo, composto por seis excertos que constituem a totalidade das falas de participantes de pesquisa nas quais existem citação do termo "estereótipo". Os seis excertos contemplam cinco temas: 1. Brasil e feriados; 2. Brasil, cinema e violência; 3. Brasil e representações negativas; 4. Identidade étnica estadunidense; e 5. Brasil, futebol e carnaval.

Eventualmente, para aprofundar a análise, fez-se uso de outros excertos que se mostraram pertinentes para a melhor compreensão dos sentidos em jogo nas falas que se dedicaram ao tema da estereotipização. A seguir, inicio a análise dos dados, abordando o primeiro tema:

\section{Brasil e feriados}

Samira (nome fictício) participa do contexto de coleta tanto como auxiliar no processo de mediação (ela era uma pesquisadora em formação), quanto como interagente (pois substituía interagentes brasileiros que precisassem se ausentar). No excerto em questão, ela interrompe a fala do professor mediador para questionar sobre algo que lhe parece recorrente nas sessões de mediação e nas interações das quais participou:

\footnotetext{
Samira: Francisco ((chama a atenção do mediador)) ... Sobre o feriado me surgiu uma dúvida... vocês chegaram a falar sobre esse estereótipo que o Brasil tem de ser o país com mais feriados... do mundo... ou se surgiu alguma questão estereotípica mesmo... em outra interação... ou que foi desmistificado? (M2.1, linhas $224-228$ )
}

A preocupação de Samira com a representação supracitada acerca do calendário brasileiro não é infundada e remonta aos estereótipos cunhados pelos europeus colonizadores sobre os indígenas que habitavam nossas terras. Assim, desde os tempos dos jesuítas, o ócio dos povos indígenas foi visto como preguiça ou falta de aptidão para o trabalho, segundo uma perspectiva que desconsiderava totalmente a história e as 
tradições desses grupos e que "autorizava", na perspectiva do colonizador, abusos de toda ordem. Cabe ressaltar, como exemplo dos ecos e da complexidade dessa representação, que Mário de Andrade, renomado pensador, poeta e prosador modernista, em Macunaíma, vale-se desse estereótipo do indígena preguiçoso para compor seu personagem, o (anti) herói brasileiro sem nenhum caráter:

\begin{abstract}
No fundo do mato virgem nasceu Macunaíma, herói da nossa gente. Era preto retinto e filho do medo da noite. Houve um momento em que silêncio foi tão grande escutando o murmurejo do Uraricoera, que a índia tapanhumas pariu uma criança feia. Essa criança é que chamaram de Macunaíma. Já na meninice fez coisas de sarapantar. De primeiro passou mais de seis anos não falando. Si o incitavam a falar exclamava: ai, que preguiça! ... (ANDRADE, 2004, p. 01) ${ }^{8}$.
\end{abstract}

Além dos indígenas, os baianos também são vistos até hoje como povo preguiçoso por grande parte dos brasileiros. Associar o povo baiano à preguiça pode remontar à época da escravidão, afinal, a Bahia é um estado brasileiro com enorme número de negros, descendentes de africanos de diferentes etnias, trazidos à força para este país com o propósito de servir como mão de obra escrava. Os escravos, sequestrados, massacrados, supliciados, por sua vez, foram também rotulados de preguiçosos, assim como os são seus descendentes até os dias de hoje, embora tenham tido papel fundamental no desenvolvimento econômico, tecnológico, estético e cultural de nossa sociedade ${ }^{9}$.

Outra hipótese a respeito do estereótipo do "baiano preguiçoso", que dialoga com a questão da escravidão, é a de que a preguiça seja um insulto que rotule e mascare a miséria e a falta de formação do povo desse estado que, como sabemos, vem de um histórico de negligências em termos de políticas públicas que remontam aos primórdios do Brasil colônia e do Brasil nação. Note que, ao impor esse rótulo, naturaliza-se a preguiça como traço cultural do povo baiano e apaga-se a negligência política, silenciase a voz dessas pessoas e estrutura-se um discurso sobre elas.

Baianos e demais nordestinos sofreram num passado recente graves insultos por parte, sobretudo, de paulistas, em um episódio vinculado a um cenário político de eleições presidenciais, no qual um partido tradicionalmente representado como de esquerda $\left(\mathrm{PT}^{10}\right)$ se opôs, pleiteando a reeleição de sua candidata à presidência, às forças de um partido de centro-direita $\left(\mathrm{PSDB}^{11}\right.$ ) apoiado majoritariamente pelo Sudeste brasileiro. Um exemplo de postagem em rede social no qual o estereótipo do nordestino preguiçoso é evocado no seio destas disputas eleitorais trazia os seguintes dizeres: "Porque o PT não invento o bolsa trabalho para vê se o Norte e o Nordeste iria votar neles? TRABALHAR NINGUEM QUER NÉ, BANDO DE VAGABUNDOS! (SIC)" ${ }^{12}$.

\footnotetext{
${ }^{8}$ ANDRADE, M. de. Macunaíma. São Paulo: Villa Rica, 2004.

${ }^{9}$ Para isso, visitar a mostra atual do Museu Afro Brasil, no Parque Ibirapuera em São Paulo, que destaca a perspectiva negra, afro-brasileira, na formação da tecnologia, do patrimônio, identidade e cultura brasileira.

${ }^{10}$ Para saber mais sobre o partido: <http://www.pt.org.br/>. Acesso em: 08 fev. 2018.

${ }^{11}$ Para saber mais sobre o partido: <http://www.psdb.org.br/>. Acesso em: 08 fev. 2018.

12 Desvios mantidos, conforme ocorrência. Disponível em:

$<\underline{\text { http://www.ipiauonline.com.br/noticias/ministerio-publico-investiga-insultos-contra-nordestinos-na- }}$ internet-apos-o-primeiro-turno-da-eleicao-15320/>. Acesso em: 21 out. 2014.
} 
Destarte, a preocupação de Samira é historicamente fundamentada e tem estreita relação com a necessidade de se desconstruir uma representação cristalizada e homogeneizante que tenta naturalizar um discurso ideológico de exclusão social construído acerca do povo brasileiro: a de que temos muitos feriados, trabalhamos menos e somos um povo preguiçoso. Note como esse estereótipo molda nossas práticas cotidianas, sobretudo o ódio entre brasileiros.

\section{Brasil, cinema e violência}

Um dos traços que mostram a complexidade da análise deste estudo é a relação próxima e colaborativa que existia entre os mediadores dos dois casos. Assim, embora os momentos de coleta sejam cronologicamente distintos (caso 1, 2011; caso 2, 2012), os participantes de cada grupo sejam quase sempre diferentes ${ }^{13}$ (com exceção de Jorge, um jovem universitário que esteve presente nos casos 1 e 2); bem como os interagentes estrangeiros sejam outros (caso 1, universitários estadunidenses; caso 2, universitários mexicanos), os mediadores eram parte de uma sólida equipe colaborativa de pesquisadores envolvidos com a prática de Teletandem. $\mathrm{O}$ que demonstra que eventos ocorridos em um contexto (caso 1, por exemplo) podem ter efeitos em outro (caso 2). Destarte, iniciarei esta etapa da análise com algumas informações circunstanciais que denotam a "atmosfera" que envolveu a segunda citação explícita a ser feita sobre estereótipos. Tratam-se de informações que retomam falas do primeiro caso (2011, português - inglês), mas que nos ajudarão a entender a citação explícita sobre estereótipos que ocorreu no segundo caso (2012, português - espanhol).

E tudo começa com o cinema brasileiro, mais especificamente com Cidade de Deus (Fernando Meirelles, 2002), uma obra cinematográfica fictícia que conta a história de um jovem negro e pobre, chamado Buscapé. O jovem Buscapé mora no complexo habitacional que dá nome ao filme, Cidade de Deus, em uma periferia da cidade do Rio de Janeiro, ele é o narrador de uma trama em que a violência e a pobreza são tematizadas, assim como o tráfico e seu poder. No excerto a seguir, extraído do caso 1, o filme fulgura como representação cinematográfica da identidade brasileira, deixando por um momento seu aspecto fictício em segundo plano:

Francisco ((mediador)): cidade de deus e falo com ele e cidade de deus é o nosso país? É BRASIL? você se assusta quando você vê cidade deus? Vocês já viram cidade de deus? (M2.1, linhas $229-232$ )

A seguir, mais um excerto da mesma mediação em que o filme Cidade de Deus é retomado, corroborando para a leitura feita acerca do excerto supracitado, a de que a indústria cinematográfica exerce um papel de influência sobre as representações de identidade e os estereótipos de um povo:

\footnotetext{
Jorge: a minha parceira não... ela perguntou assim.... ah mas eu sei eu assisti esse filme eu assisti outros filmes brasileiros e eu vi pesquisei conversei... eu vi que a CIDADE DE DEUS não é a realidade do Brasil... mas ela falou assim mas que os outros amigos que só assistiram cidade de deus... prá eles... o Brasil é uma favela é um tiroteio é: a cidade de deus. (M2.1, linhas 240 244).
}

\footnotetext{
${ }^{13}$ Caso 1, aprendizes de inglês; caso 2, aprendizes de espanhol.
} 
Com as alusões feitas acerca do filme em questão, fica evidente a representação tomada pelos participantes do estudo como estereotípica do povo brasileiro: a de que somos violentos, pobres e sucumbimos ao poderio dos traficantes. E, embora essa seja uma representação coerente com a realidade que assola grande parcela da população brasileira, ela é rejeitada pelos interagentes que participaram da coleta no caso 1, assim como pelos participantes e pela mediadora do caso 2, conforme fica evidente no excerto a seguir, que se configura como nosso terceiro excerto a conter citação direta do termo estereótipo.

\subsection{Agora sim, o excerto sobre Brasil, cinema e violência: Carandiru e Tropa de Elite}

No excerto a seguir, o tema "Brasil, cinema e violência" é contemplado tomando como referência as seguintes obras cinematográficas: Carandiru (filme que aborda a vida de detentos em um presídio de São Paulo, perpassando por um episódio de massacre; o filme é baseado em uma obra intitulada Estação Carandiru que relata a experiência real de seu autor, Dr. Drauzio Varella, enquanto médico voluntário envolvido em um projeto de prevenção de doenças sexualmente transmissíveis no presídio); Tropa de Elite (filme fictício que aborda a perspectiva de um capitão no combate ao tráfico de drogas no Rio de Janeiro, o filme é recheado de cenas de violência, de tortura policial e morte). Assim, de certa forma, Cidade de Deus, Carandiru e Tropa de Elite formam uma trilogia de obras que representam uma leitura cinematográfica da violência e da miséria no Brasil. Podemos dizer que, entre os interagentes brasileiros, a grande repercussão internacional dessas obras gera desconforto, sendo essas associadas à possibilidade de cristalização de representações sobre o Brasil, e, assim, favorecendo a formação de estereótipos. É o que podemos notar no excerto a seguir:

Jorge: eu tenho: ((nome de colega interagente)) ... eu fiz uma lista semestre passado pro meu parceiro que até eu vou mandar pra esse agora... eu acho que tinha quinze filmes brasileiros SEM colocar Carandiru: esses...

Kristin ((mediadora)): tropa de elite...

Janaina ((mediadora)): AH não porque: cê não põe essas coisas: esses estereótipos não!

Jorge: esses mais cabeças e: o mais violentinho que tinha era verônica de uma professora da periferia... o restante mais: (M3.2, linhas $323-329)$.

A censura ao que é tomado como veículo de disseminação de uma representação estereotípica do Brasil, os filmes supracitados, que aparece em "AH não porque: cê não põe essas coisas: esses estereótipos não!" (M3.2, linha 327), só é possível porque a representação de um país entregue ao tráfico, à miséria e à violência existe e incomoda, pois essa representação engendra um sistema interpelativo (BUTLER, 1999; ALTHUSSER, 1970) do qual nossos participantes de pesquisa querem se desvencilhar.

Trata-se de um movimento de antecipação por parte dos mediadores, na tentativa de conter o avanço da disseminação de uma representação indesejada do Brasil. Mas o que ainda pode ser questionado aqui é: (a) "por que, dentre inúmeras representações cinematográficas do Brasil, essas se inscreveram na memória dos estudantes envolvidos na coleta de dados como relevante enquanto representação de um povo/ nação?", ou 
(b) "o que as representações em jogo nessas transcrições deflagram como repetições constitutivas (ou padrões) da identidade brasileira (e o que elas necessariamente apagam)?", (c) "o que o movimento de censura às produções cinematográficas que se filiam a esse problema ali instaurado acerca de nossa identidade deflagra sobre estereótipos?".

Uma nova pesquisa, seguida de uma análise semiótica dos filmes em questão, seria necessária (e talvez insuficiente) para que fossem esgotadas as razões que levam determinadas materialidades ou formulações (e não outras) a se inscreverem na memória de algumas pessoas a ponto de engendrarem cristalizações estereotípicas (questionamento do parágrafo anterior).

Contudo, se elas engendram tais cristalizações, torna-se coerente considerar que isso aconteça porque essas materialidades ou formulações encontraram "eco", ou alguma forma de relação, com um certo conjunto de saberes já socialmente sistematizados. Ou seja, elas se cristalizam porque significam e significam porque são significadas (e não por que são a verdade em si), pois são relacionadas a outras formulações possíveis, outras materialidades simbólicas, existentes ou imaginadas, que compõem um conjunto de realizações potenciais acerca de um determinado povo ou nação.

O questionamento b, sobre "o que" essas representações cristalizadas "deflagram", pode ser respondido se for levado em conta o jogo de antecipação, marcado pelo movimento de censura (que nos remete ao questionamento c, mostrandonos que as questões são imbricadas), presente no excerto sobre estereótipo. Afinal, a censura planejada acerca de quais filmes devam ser silenciados nas trocas entre interagentes (marcada em "sem colocar Carandiru... esses" e "cê não põe essas coisas e esses estereótipos não") marcam um movimento antecipatório frente a um desconforto real, uma dor de ver outro interpelar você e sua nacionalidade pelo viés das representações trazidas nessas obras cinematográficas. A reflexão deflagrada até então evidencia indícios contra a pretensa inofensibilidade das construções estereotípicas sobre nacionalidades e culturas.

\section{Brasil e representações negativas}

O excerto a seguir, extraído também do material do documentário referente ao caso 1, corrobora essa leitura acerca do sentimento de incômodo que os estereótipos negativos imprimem em quem é alvo da estereotipia:

Francisco ((mediador)): ((nome de interagente)) pintou alguma coisa entre vocês? ele fez perguntas?

\footnotetext{
Alberto: não... ele não fez perguntas ele falou assim.... ele deu a entender o estereótipo do Brasil no mundo é um pouco negativo né?

Francisco: nem sempre...

Alberto: o Brasil então...

Francisco: Nem sempre: a gente tá com um... com uma altíssima lá fora.
} 
Alberto: ele demonstrou que... ((sobreposição de falas incompreensíveis)) o Rio de Janeiro por exemplo... Nem todo norte-americano é bom então... da mesma forma que aparece o Brasil na mídia... é verdade.

Francisco: então: quer dizer que pintou uma espécie de... tensão... ou comparação?

\begin{abstract}
Alberto: Existe essa tensão... mas na realidade ele... percebe-se que existe... huh... pelo menos na concepção dele.... um estereótipo do... dos problemas do Brasil.... pelo menos o que está passando por último agora no Brasil né? (M2.4, linhas 178 - 190).
\end{abstract}

É importante frisar que, na ocasião da coleta dos dados, em 2011, o Brasil ainda era visto como país economicamente ascendente e estável, sobretudo por ter resistido à grande crise internacional que eclodiu em 2008 com o estouro da bolha imobiliária americana. Prova disso são as repercussões jornalísticas acerca da economia brasileira, sobretudo, em novembro de 2009, quando a influente revista The Economist estampou em sua capa a imagem do Cristo Redentor alçando voo para o alto, em ascensão. Essa representação da emblemática escultura carioca voltou a ser referência internacional na capa da mesma revista em 2013, mas nesse ano nosso Cristo era representado voando rumo ao chão, prestes a colidir, seguido da pergunta: "Has Brazil blown it?" ou, em tradução livre, "O Brasil estragou tudo?"14.

Destarte, quando o mediador Francisco cita que "estamos com uma altíssima lá fora" (M2.4, linha 183), ele faz referência à leitura positiva que se fazia internacionalmente sobre a economia brasileira ainda em 2011, mas que já estava em processo de desconstrução e, pela fala do interagente Alberto, já não era uma leitura suficiente para enfrentar a representação negativa que seu parceiro estadunidense demonstrou a ele durante a interação, representação essa que Alberto rotulou como estereotípica.

Assim, temos um exemplo de como os estereótipos resistem aos fatos, afinal, por ocasião da coleta, o fato histórico era o relativo sucesso econômico brasileiro e as perspectivas positivas para seu futuro, mas a representação vigente entre os interagentes era negativa, persistente, e interpelativa de modo que situava em relação desigual de poder o interagente brasileiro em relação ao seu par estadunidense. Desta forma, leituras essencialistas sobre estereótipos (que os mostram como reflexo de traço repetitivo ou proeminente de um povo ou cultura) parecem não ser adequadas.

\title{
4. Identidade étnica estadunidense
}

Abaixo, serão apresentados dois excertos em que a relação estereótipo e etnia é tecida por interagentes do caso 2 (M2.5, linhas 88 - 98; e, M2.5, linhas 465 - 475). Nesses dois exemplos, uma dada nacionalidade passa a ser pressuposta pela aparência da pessoa de quem se fala. Analisemos o primeiro excerto:

Francisco ((mediador)): ... ((chama pelo nome da participante do estudo)) você falou que a cara do parceiro dela é meio estereótipo... o que é isso?

Carla: ((incompreensível)) ... o: parceiro... sabe: branquinho magrinho lourinho... não é um... um... ((incompreensível)) aparente... físico que a gente costuma ver aqui no Brasil.... assim

14 É possível comparar as duas capas de revistas no site: $<\underline{\text { http://economia.uol.com.br/noticias/redacao/2013/10/09/apos-economist-ny-times-e-wall-street-journal- }}$ criticam-economia-do-brasil.htm>. Acesso em: 21 out. 2014. 
porque por causa da mistura de raças e tudo... tá? eu não vou dizer assim.... é.... puro sangue... mas eles são BEM IGUAIZINHOS... assim.... lourinhos... branquinhos... não é como isso aqui no Brasil... A gente vê um ou outro... ou vê no sul.... assim.... então é uma cara bem de americano só olha e fala É AMERICANO! na minha igreja a gente... eu tenho... uma amiga lá e ela ficou noiva de um americano ele veio para o Brasil e eu olhei assim.... de longe... ela nem estava perto... daí eu falei... ia muita gente na igreja... eu falei aquele que é seu noivo? ... ela... ai como você sabe? ... eu... cara de americano... é assim mesmo! ((risadas)) (M2.5, linhas 88 - 98)

Por traz das colocações de Carla (nome fictício), podemos identificar as seguintes pressuposições: a. existe pureza étnica ("eu não vou dizer assim.... é.... puro sangue"), b. a pureza étnica se refere a espaços geográficos, a Estados ou Nações ("não é como isso aqui no Brasil.... a gente vê um ou outro... ou vê no sul.... assim... então é uma cara bem de americano só olha e fala É AMERICANO!"), c. a relação entre etnia e espaço geográfico pode ser traçada facilmente, basta um olhar ("eu olhei assim... de longe... ela nem estava perto... daí eu falei... ia muita gente na igreja... eu falei aquele que é seu noivo?... ela... ai como você sabe?”). Mas o que estaria por trás desse discurso seria uma ideologia racista, que legitima preconceitos e estereótipos ao naturalizar (CHAUÍ, 1980) a relação entre aparência e espaço geográfico. Ao se posicionar do modo como fez, Carla legitima, talvez involuntariamente, um sistema de relações sociais de exclusão e favorece a manutenção das ideias que sustentam esse sistema e servem aos propósitos de um determinado grupo social, que não identificamos explicitamente no excerto, mas que remete a imaginários semelhantes ao imaginário nazista, bem como ao imaginário escravocrata, por exemplo. Essa formação estereotípica dialoga com os casos atuais de racismo e ódio em Charlottesville ${ }^{15}$, nos Estados Unidos da América, por exemplo.

\section{Brasil, futebol e carnaval}

Adiante, um excerto no qual uma interagente relata os temas abordados em sua interação com um parceiro mexicano. Ao longo de seu relato, ela demonstra ter interpelado seu parceiro a se posicionar acerca dos estereótipos sobre o Brasil pela perspectiva da nacionalidade dele:

((voz feminina)): Bom... a gente chegou a comentar sobre o carnaval por que ... a gente conversou mais sobre cultura hoje... então ele: ele falou: ((incompreensível)) eu perguntei para ele que: ele como mexicano o que ele pensava sobre o país dele... então... daí ele fez... ele falou um pouco sobre o país dele... falou sobre os indígenas... sobre a discriminação que eles sofrem lá... daí depois ele fez... eu perguntei... ele como mexicano quais eram os estereótipos... o que eles pensavam do Brasil... daí foi que: daí surgiu o carnaval... o futebol e essas coisas (M3.4, linhas 9 - 15).

Vejam que, ao perguntar ao parceiro sobre os estereótipos brasileiros, o parceiro prontamente elenca a dupla carnaval e futebol. Esse é o tipo de cristalização estereotípica aparentemente inofensiva, que faz parecer que nada há de mal na veiculação desse estereótipo. Essa fórmula funciona bem porque o caráter reducionista e massificador desses estereótipos (do Brasil como país do carnaval, e do Brasil como país do futebol) é apagado, bem como são apagadas e impossíveis de se reestabelecer as suas origens.

15 Para saber mais: < http://internacional.estadao.com.br/noticias/geral,agressao-racista-abala-cidade-demaioria-branca-e-democrata,70001935156>. Acesso em: 20 set. 2015. 
A História é capaz de nos evidenciar as razões pelas quais essa formulação em especial se faz perigosa. Peguemos o exemplo do seguinte estereótipo: Brasil, país do futebol e, para avaliar o problema engendrado por essa formulação, relatarei um breve fato, envolvendo a diplomacia nacional.

No dia 24 de julho de 2014, o porta-voz do Ministério das Relações Exteriores de Israel, Yigal Palmor, declarou seu descontentamento frente ao posicionamento do governo brasileiro acerca dos conflitos entre Israel e os palestinos que habitam a faixa de Gaza. Como amplamente noticiado em redes nacionais e internacionais, Yigal Palmor afirmou que o Brasil dava "uma demonstração lamentável" de como, apesar de ser "um gigante econômico e cultural", continuava a ser "um anão diplomático"16.

O caso teve grande repercussão midiática, inclusive nas redes sociais, o que levou o governo brasileiro a se justificar, alegando que seu posicionamento estava atrelado ao fato de que havia uso desproporcional de força militar empregada no conflito por parte do exército israelense e que muitos civis palestinos, incluindo crianças, já haviam perdido suas vidas. A justificativa brasileira, por sua vez, provocou uma reação por parte do porta-voz israelense que culminou em seu afastamento do Ministério das Relações Exteriores de Israel.

Segundo Yigal Palmor, o uso de força bélica contra a faixa de Gaza não seria desproporcional, ao passo que perder de sete a um, sim, seria. Nas palavras do porta-voz israelense (tradução nossa): "Isto não é futebol. No futebol, quando um jogo termina com um empate, você acha que é proporcional, mas quando termina 7-1 é desproporcional. Desculpe dizer, mas não é assim na vida real e no direito internacional." " ${ }^{17}$. A fala do representante israelita evocava o episódio em que o time de futebol brasileiro perdeu de sete gols contra um para o time de futebol alemão, por ocasião do final da Copa do Mundo de Futebol sediada no Brasil entre junho e julho de 2014. Ao fazer tal evocação, a fala de Palmor almejava ser ofensiva, pois usou de um dos símbolos internacionalmente difundidos como referência da identidade nacional brasileira, o futebol, para desprestigiar o posicionamento diplomático do Brasil e, assim, materializou-se como uma fala interpelativa, porque evocou um quadro rígido de representações ao qual se espera que o Brasil esteja atrelado (como país do samba, do futebol, das praias e das mulheres disponíveis para encontros casuais).

Por ser interpelativa, a fala materializou um discurso muito claro: o de que a nação brasileira deve se ater aos assuntos de futebol, pois diplomacia e direito internacional não seriam "de sua alçada". Ou seja, delimitando qual é o lugar do Brasil no mundo: como país para entretenimento.

\footnotetext{
16 Para saber mais, consultar: <http://g1.globo.com/jornal-nacional/noticia/2014/09/israelense-quechamou-brasil-de-anao-diplomatico-deixa-o-cargo.html $>$; $<$ http://www.washingtonpost.com/blogs/worldviews/wp/2014/07/25/israel-brings-up-brazils-world-cuphumiliation-and-calls-the-country-a-diplomatic-dwarf/>. Acesso em: 20 out. 2014.

${ }^{17}$ Original: "This is not football. In football, when a game ends in a draw, you think it is proportional, but when it finishes 7-1 it's disproportionate. Sorry to say, but not so in real life and under international law". Disponível em: <http://www.washingtonpost.com/blogs/worldviews/wp/2014/07/25/israel-brings-upbrazils-world-cup-humiliation-and-calls-the-country-a-diplomatic-dwarf/>. Acesso em: 20 out. 2014.
} 


\section{Considerações finais}

Este artigo traz um estudo inicial a respeito dos sentidos evocados quando os estereótipos sobre nacionalidades e culturas são abordados em um contexto telecolaborativo de aprendizagem de línguas estrangeiras. Ao se realizar uma análise interpretativista a respeito dos dados apresentados, foi possível confirmar a hipótese de que os participantes deste estudo, ao tratarem do tema "estereótipos", transitaram entre os universos de suas experiências pessoais e das memórias e saberes socialmente partilhados, historicamente inscritos, em uma dinâmica de interpelações e assujeitamentos que, muitas vezes, se esconde nos silêncios e nos apagamentos constitutivos de toda forma de enunciação.

Os estereótipos sobre nacionalidades e culturas, conforme a análise dos dados evidenciou, mostraram-se como ferramentas ideológicas de discriminação, preconceito, e de manutenção de estruturas políticas (raciais, étnicas, nacionais, internacionais) de poder que funcionam para sedimentar e justificar divisões e classificações que podem dificultar uma comunicação efetiva entre aprendizes de uma língua estrangeira, por exemplo, mas também afetam as relações entre dois sujeitos estrangeiros em quaisquer outros contextos sociais, como Baccega (1998) e Birolli (2010) sinalizam.

Desta forma, os estereótipos se mostram como um tema de suma importância para a formação docente, discente, política e cidadã, constituindo-se um elemento cuja discussão e enfrentamento, nos diversos espaços e práticas sociais, torna-se fulcral para o desenvolvimento de sujeitos mais conscientes e dispostos a contribuir de maneira significativa para a construção de uma relação mais igualitária e onde haja menos "préjuízos" (BACCEGA, 1998) entre os que possuem gentílicos diferentes.

\section{REFERÊNCIAS}

ALTHUSSER, L. Ideologia e Aparelhos Ideológicos de Estado. Lisboa: Presença 1970.

BACCEGA, M. A. O Estereótipo e as Diversidades. Comunicação \& Educação, São Paulo, p. 7-14, set./dez. 1998.

BOSI, E. Entre a opinião e o estereótipo. Novos Estudos, CEBRAP, n. 32, p. 111-118, mar. $1992 . \quad$ Disponível em: $<$ http://novosestudos.org.br/v1/files/uploads/contents/66/20080625 entre_a_opiniao_e o_estereotipo.pdf>. Acesso em: 03 mar. 17.

CANCLINI, N. G. Leitoras, espectadores e internautas. São Paulo: Iluminuras, 2008.

CHARMAZ, K. A construção da teoria fundamentada: guia prático para análise qualitativa. Tradução de J. Elias. Porto Alegre: Artmed, 2009.

Grounded Theory in the 21st Century: Applications for Advancing Social Justice Studies. In: DENZIN, N. K.; LINCOLN, Y. S. (Eds.). The Sage Handbook of Qualitative Research. 2nd. ed. Thousand Oaks: Sage, 2000. p. 507-531.

CHAUÍ, M. S. Ideologia e Educação. Revista Educação e Sociedade, São Paulo: Cortez, n. 5, p. 245-257, jan. 1980. 
FUNO, L. B. A. Teletandem: um estudo sobre identidades culturais e sessões de mediação da aprendizagem. 2015. 190 f. Tese (Doutorado em Estudos Linguísticos) Instituto de Biociências, Letras e Ciências Exatas, Universidade Estadual Paulista, São José do Rio Preto, 2015. Disponível em:

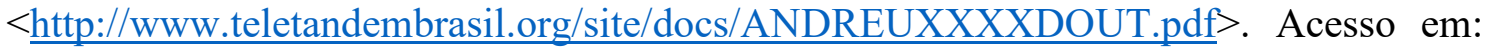
26 out. 2015.

GILHAN, B. Case Study Research Methods. London: Continuun, 2000.

LIPPMANN, W. Public opinion. New York: Free Press, 1965[1922].

ORLANDI, E. P. Cidade dos Sentidos. São Paulo: Pontes, 2004.

PEREIRA, M. E. Psicologia social dos Estereótipos. São Paulo: E.P.U, 2002.

PEREIRA, M. E.; MODESTO, J. G.; MATOS, M. D. Em direção a uma nova definição de estereótipos: teste empírico do modelo num primeiro cenário experimental. Psicologia e Saber Social, v. 1, n. 2, p. 201-220, 2012. Disponível em: <http://www.epublicacoes.uerj.br/index.php/psi-sabersocial/article/view/4899/3622>. Acesso: 05 mar. 17.

Recebido em: 25/09/2017

Aprovado em: 15/02/2018 